\title{
Editors' introduction: precarious lives and Syrian refugees in Turkey
}

\author{
Mine Eder and Derya Özkul
}

no one leaves home unless home is the mouth of a shark

you only run for the border when you see the whole city running as well

you have to understand, that no one puts their children in a boat unless the water is safer than the land

Warsan Shire, from "Home"

This special issue aims to map out different dimensions of the economic, social, and political uncertainties, the precariousness, the insecurity, and the "othering" that migrants, particularly Syrian refugees, are currently facing in Turkey. As of April 2016, Turkey hosts 2.7 million registered Syrian refugees, making it the largest recipient of refugees in the world in the post-World War II era; this is also the biggest influx of refugees in republican history. It is a serious humanitarian crisis as well, with nearly half of the Syrian population having either been internally displaced (at least 7.6 million) or become refugees (4.8 million). ${ }^{1}$ Despite the Turkish government's "open door" policy since the start of the Syrian conflict and the ten billion dollars spent on refugee camps and public service provisions, Syrian refugees and other migrants into Turkey enter into an already precarious and informal labor market: their legal status is in limbo and their "incorporation" into society has remained slow and

Mine Eder, Boğaziçi University, Department of Political Science and International Relations; Derya Özkul, The University of Sydney, School of Social and Political Sciences.

Authors' Note: Special thanks to the participants of the workshop "Social Transformation and International Migration in Turkey," which took place at Boğaziçi University on January 8-9, 2015. Most of the ideas for this special issue initially developed there. We also thank the anonymous reviewers and journal editors for their invaluable contributions.

1 Norwegian Council and Internal Displacement Monitoring Center Global Overview 2015 http://www.internal-displacement.org/assets/library/Media/201505-Global-Overview-2015/20150506global-overview-2015-en.pdf and UNCHR Syria Regional Refugee Response http://data.unhcr.org/ syrianrefugees/regional.php 
insufficient at best. Understanding their precariousness or the attendant "modalities of dehumanization" can help us rethink not only Turkey's migration regime in particular, but also the broader context of the failure of the international community to protect migrants and refugees.

As most migration studies acknowledge, the condition of migrants is entangled with and reflects the existing social, economic, and political transformations taking place in both the receiving and sending country. ${ }^{2}$ Hence, there is a need to place the migrants in the larger context of social transformation in Turkey, and we hope in this volume to offer an overview of how the migrants, with particular focus on the recent Syrian refugees, fit into this larger picture. This bird's-eye view of Turkey's socioeconomic and political context, we suggest, may partially explain why the Syrian refugees want to leave Turkey, risking their lives in doing so, and why they have sought to evade deportation from the European Union (EU) after the March 2016 EU-Turkey deal, according to which all new irregular migrants passing from Turkey to Greece will be returned to Turkey. ${ }^{3}$

With 60 million people either as refugees or internally displaced around the world, one obvious common theme of this special issue is the failure of global governance mechanisms and the international community to respond to catastrophic humanitarian crises. ${ }^{4}$ As Nergis Canefe, Burcu Toğral Koca, and Sema Erder all point out, the international community has been quite reluctant and slow in tackling the humanitarian side effects of the Syrian conflict, and the image of the body of the three-year-old Syrian Aylan Kurdi washed ashore has become a telling symbol of this failure and dehumanization. Sema Erder and Nergis Canefe describe how the refugee management system based on establishing security zones and refugee camps close to the conflicts, as well as arduously and slowly placing "selected" refugees in third countries based on market needs, has become simply unsustainable. But despite the doubling of asylum applications in Europe in 2015 (reaching 1.2 million, predominantly Syrians, Afghanis, and Iraqis) and the intensification of refugee flows into Europe, old-style migration management combining "securitization" and controlled, "market-informed" access has still been very much at work—not

2 Stephen Castles, Derya Özkul, and Magdalena Arias Cubas, eds. Social Transformation and Migration: National and Local Experiences in South Korea, Turkey, Mexico and Australia (Basingstoke: Palgrave, 2015).

3 The deal also envisions that for every Syrian being returned to Turkey from the Greek islands, another Syrian will be resettled in the EU; however, this process is very slow and resettlement numbers are likely to be very low. For details of the deal, see http://europa.eu/rapid/press-release_MEMO-16963_en.htm.

4 Elizabeth Ferris and Kemal Kirişci, The Consequences of Chaos: Syria's Humanitarian Crisis and the Failure to Protect (Washington DC: Brookings Institution Press, 2015). 
much has changed on the Western front. ${ }^{5}$ Deep divisions within the EU regarding refugee management and the March 2016 EU-Turkey deal, mostly aiming to stop irregular migration from Turkey into Europe and often tagged as a "dirty" deal, suggest that the idea of "Fortress Europe" is alive and well. The rise of xenophobia and the political far right, which try to establish links between migration and terrorism, also shows that the much-needed selfreflection on migration and refugee management has yet to begin in Europe.

The result has been an intensification of uncertainty, precarity, and economic vulnerability for the migrants, concepts that are most frequently used in this volume to depict their dehumanizing conditions. Canefe places the discussion of Syrian refugees in the context of Turkey's overall irregular migration, suggesting that migrants and refugees constitute a growing army of precarious labor that is in high demand as a result of the structural position of the country in the global economy. Despite all the pretense of managing irregular migration, new growth economies like Turkey, she argues, depend and thrive on this cheap and flexible labor. The recent changes in Turkey's labor laws, designed to normalize and legalize flexible and temporary work, represent but a small example of how Turkey's approach to migration has become conveniently compatible with its neoliberal transformation.

Similarly, using the case of seasonal agricultural work, Sinem Kavak focuses on the economic uncertainty and fragility of those Syrian refugees who join the existing army of the informal seasonal migrant labor force, which is already operating in precarious labor markets. She argues that the existing poverty and lack of sufficient jobs with decent pay pits one poor person against another, with migrants and non-migrants competing for the shrinking pool of low-paying, temporary jobs. This "adverse incorporation" into Turkey's labor markets contributes to the growing army of the "working poor," who are locked into chronic poverty, often with little or no exit-a condition of hyper-precarity. ${ }^{6}$ Both Canefe and Kavak underscore the importance of seeing precariousness as a relational concept and as a continuum, bundled together with poverty, exclusion, and the increasing informality and inequality in Turkey.

5 See http://ec.europa.eu/eurostat/documents/2995521/7203832/3-04032016-AP-EN.pdf/790eba01381c-4163-bcd2-a54959b99ed6.

6 These terms are borrowed from Guy Standing, The Precariat: The New Dangerous Class (London and New York: Bloomsbury Academic, 2011); Sam Hickey and Andries du Toit, "Adverse Incorporation, Social Exclusion and Chronic Poverty," Chronic Poverty Research Centre Working Papers No. 81 (Manchester: University of Manchester, 2007): 134-159; and Hannah Lewis, Peter Dwyer, Stuart Hodkinson, and Louise Waite, "Hyper-precarious Lives: Migrants, Work and Forced Labour in the Global North," Progress in Human Geography 39, no. 5 (2015): 580-600. 
This rush to create an army of "precariats" is clearly not unique to Turkey, but part of a global trend. ${ }^{7}$ In her article, Deniz S.. Sert adds another important dimension to this precariousness by describing how and why most migrants, even those with higher cultural capital and occupational qualifications in Turkey, go through a process of dequalification and deskilling. Accreditation problems, language barriers, lack of information, and identity-based discrimination further complicate the already difficult lives of migrants in Turkey.

Placing migration into the context of Turkey's neoliberal transformation and precarious labor markets also helps us avoid the misleading binary categories of forced/voluntary, formal/informal, legal/illegal, and migrant/ non-migrant labor. Such an approach can help explain the seeming paradox of why the influx of Syrian refugees has led to a "large-scale displacement of Turkish workers from the informal sector, around 6 natives for every 10 refugees" while simultaneously boosting economic growth, consumption, and investment. ${ }^{8}$ This is also why most neoliberal economists confirm that migration bolsters economic growth in host countries, creating opportunities as well as challenges-none, however, question whether this type of unequal growth based on cheap(er) and (more) flexible labor is actually sustainable or desirable.

Burcu Toğral Koca elaborates on this "wanted but not welcome" phenomenon by making use of the securitization literature. ${ }^{9}$ She points to the apparent paradox between Turkey's open door policy and the humanitarian discourse of brotherhood and inclusion ("historical and geographical necessities," "religious fraternity," "ethnic kinship") when it comes to acceptance of Syrian refugees, as well as the growing securitization and perception of threat regarding domestic labor markets and employment opportunities. Casting a sharp critical eye on Turkey's refugee regime, she points to the overemphasis on control and containment through "[a]n imprecise legal framework, militarized border controls, limited secure 'legal' status, restricted access to social rights, and the encampment of refugees [which] all have preventive and security aspects." She demonstrates

7 Carl-Ulrik Schierup, Ronaldo Munck, Branka Likić-Brborić, and Anders Neergaard, eds. Migration, Precarity, and Global Governance: Challenges and Opportunities for Labour (Oxford: Oxford University Press, 2015).

8 Ximena V. Del Carpio and Mathis Wagner, The Impact of Syrian Refugees on the Turkish Labor Market, World Bank Social Protection and Labor Global Practice Group, Policy Research Working Paper 7402 (August 2015): 4. For a positive, market-friendly assessment, see Murat Erdoğan and Can Ünver's report for the Turkish Confederation of Employer Associations (Türkiye İşveren Sendikaları Konfederasyonu, TiSK): "Türk İş Dünyasının Türkiye'deki Suriyeliler Konusundaki Görüşleri ve Beklentileri" (2015), http://tisk.org.tr/tr/e-yayinlar/353-goc/353-goc.pdf.

9 Aristide Zolberg, "Wanted but Not Welcome: Alien Labor in Western Development," in Population in an Interacting World, ed. William Alonso (Cambridge: Harvard University Press, 1987): 36-73. 
that non-camp Syrian refugees in Turkey, who constitute 85 percent of all Syrian refugees, have become the "new other" subject to discrimination and exploitation.

Indeed, after the initial humanitarian response, and with the growing recognition that Syrian refugees are no longer "temporary guests" and are likely to settle, anti-immigrant sentiments and xenophobia appear to be on the rise. ${ }^{10}$ Also troubling is the risk of "urban segregation," where Syrian refugees either live in their own quarters or, even if they live side by side with the locals, do not really socialize or engage in social interaction. This may even be true for those who have helped or donated cash or material aid to Syrian refugees. ${ }^{11}$ Unfortunately, systematically low levels of interpersonal trust in Turkish society, as well as already low levels of civil society engagement and non-conventional political participation, suggest that this lack of human interaction is not exclusive to Syrian refugees.

Further complicating the picture has been the legal ambiguity that the Syrian refugees face in Turkey, another common theme in this issue that only adds to their hyper-precariousness. The new law on foreigners and international protection, which went into effect in 2014, has kept the geographical limitation of the 1951 Geneva Convention, which declared that Turkey does not grant refugee status to people coming from outside of Europe. It was some three years later when the government finally issued the Temporary Protection Directive in 2014, aimed at reducing this ambiguity by granting Syrian "guests"-once they are registered-indefinite residence, emergency access to basic needs, and no forcible returns (non-refoulement), as well as access to healthcare and education. The 2016 Regulation on Work Permit of Refugees under Temporary Protection also created ways to obtain work permits, particularly for Arabic-speaking doctors, nurses, and teachers.

However, as the authors in this volume point out, the overall migration regime in Turkey falls significantly short of a rights-based migration policy framework, and was already problematic long before the Syrian refugee crisis. As Turkey increasingly became an immigration country, problems such as the

10 Emre Erdoğan, "Unwanted, Unwelcome: Anti-immigrant Attitudes in Turkey" (September 2014), http://www.gmfus.org/publications/unwanted-unwelcome-anti-immigration-attitudes-turkey.

11 "I have donated one of my houses for the Syrians," said one shopkeeper in a commercial district in Istanbul, "but I will never allow a Syrian [to] set foot in my store"; see Mine Eder, "Perceptions of Irregular Migrants in an Informal Economy: A Pilot Study in Osmanbey and Laleli," TÜBITAK Project 114 K797.

12 See Ali Çarkoğlu and Ersin Kalaycıoğlu, "Citizenship in Turkey and the World," TUBiTAK Project 112K157 (2014), http://bilimakademisi.org/wp-content/uploads/2015/12/Türkiyede-ve-DunyadaVatandaslik-2014-1.pdf. 
implementation of the existing laws, enormous disparities in interpreting the laws, administrative leeway and immunity regarding mistreatment of migrants, and arbitrary practices, not to mention a lack of protection (or absence of legal resort) against abuses, became all too common. Whether it was the "suitcase traders" from the post-Soviet world, Afghanis, Iraqis, or Nigerians, and whether it was transit or circular migrants, these legal uncertainties have constantly blurred the lines between legality and illegality, leaving the migrants in constant limbo. ${ }^{13}$ If anything - though much more work needs to be done on this issue-the "relative privilege" of Syrian refugees in terms of legal and welfare entitlements has already started to create tensions among the various migrant groups (as well as among the "natives," as Toğral Koca rightly points out).

As Amartya Sen suggests, most countries face serious problems in transforming "entitlements" into capabilities. ${ }^{14}$ This difficulty also explains why emerging economies like Turkey-which has experienced significant economic growth and has actually increased social spending-have not shown the same success in terms of human development indicators. In fact, most observers of the transformation of Turkey's welfare regime systematically point out that the country has increasingly moved towards a "social assistance state," as well as an increasing role for the private sector and NGOs in welfare provision, which is essentially compatible with the neoliberal shift rather than a rights-based welfare system. ${ }^{15}$ As a country that never had a full-fledged mature welfare state to begin with, and which had long relied on indirect and/or informal welfare provision mechanisms such as agricultural subsidies, informal housing and family networks, this move can also help explain the persistence of relative poverty and inequality in the country. It is therefore hardly surprising that, despite rising international funding for refugees, which was slow at the beginning, and despite the money the Turkish government spent (particularly on healthcare and education), improvements in the livelihoods of Syrian refugees has remained limited. ${ }^{16}$ Similarly, the usual ad hoc migrant incorporation into the informal economy, which has long been the predominant norm, as well as unsystematic

13 For a good example, see Zeynep Kaşlı and Ayşe Parla, "Broken Lines of II/Legality and the Reproduction of State Sovereignty: The Impact of Visa Policies on Immigrants to Turkey from Bulgaria," Progress in Human Geography 34, no. 2 (2009): 203-227.

14 Amartya Sen, "Development: Which Way Now?" Economic Journal 93, no. 372 (1983): 745-762.

15 Ayşe Buğra and Çağlar Keyder, "The Turkish Welfare Regime in Transformation," Journal of European Social Policy 16, no. 3 (2006): 211-228; Tim Dorlach, "Prospects of Egalitarian Capitalism in the Global South: Turkish Social Neoliberalism in Comparative Perspective" Economy and Society 44, no. 4 (2015): 519-544.

16 World Bank, Turkey's Response to the Syrian Refugee Crisis and the Road Ahead (December 2015), http://www-wds.worldbank.org/external/default/WDSContentServer/WDSP/IB/2015/12/21/090224b08 3ed7485/1_0/Rendered/PDF/Turkey0s0respo0s0and0the0road0ahead.pdf. 
welfare provision through the private sector and NGOs, have proven $\underset{\mathrm{m}}{\mathrm{z}}$ insufficient in addressing the economic vulnerability of Syrian refugees. ${ }^{17}$

Even more problematic is the fact that the capacity of ethnic/religious kinship and social capital networks, which are so crucial in migrant incorporation, also appear to be limited in terms of their ability to overcome the precariousness of Syrian refugees. Gülay Kılıçaslan explores this particular issue through the encounters and relationships between internally displaced Kurds who arrived in the city in the 1990s and the new Syrian Kurdish refugees in two İstanbul neighborhoods. She observes that, even though ethnicity and identity-based solidarity are still crucial, these relationships can become tense and even exploitative when it comes to competing for the ever-shrinking number of informal jobs and the "right to the city." It is, she argues, precisely by studying these contestations and solidarities and ambiguous relationships emerging in "everyday life" that we can begin to understand certain migrant experiences and explore modalities of living together.

This "living together" at the micro-level ultimately necessitates a political and social environment that promotes mutual understanding, tolerance, and human encounters. This is why the ultimate guide to understanding migrants and refugees in Turkey today must involve a discussion on democratization in the country. The escalation of the Kurdish conflict and the intense violence in the southeast of the country, rising urban terrorist attacks, the regional and international entanglements of the Kurdish problem with the Syrian war, and instability in the Middle East all clearly create serious pressures. But the rapid drift of the country toward an authoritarianism with an excessive concentration of executive power, serious curbs on the freedom of expression and the press, along with a rising nationalism, all raise serious questions as to whether such democratization is possible. Even more problematic is the excessive polarization in the country over a wide range of issues. Under these conditions, a full-fledged political and social dialogue on migration and/ or refugees, their rights, and their incorporation into the country becomes impossible.

Can Turkey be a "safe haven" for migrants and refugees where economic, social, and political rights are not fully protected to begin with? This is a question the EU has conveniently ignored in its own "refugee panic." But it is the ultimate question that we will have to answer in order to stop seeing people putting their children on boats and risking their lives. After all, unless the international community, the EU, and Turkey all step up to the plate, in a world of globalized precarity, wars, rising authoritarianism, xenophobia, and dehumanization, we might all be rushing to those boats-but there may not be any place left to go.

17 Schoolchildren are particularly vulnerable: only an estimated 30 percent of school-age Syrian children can actually attend school. For the informal incorporation mechanisms, see Didem Danış, JeanFrançois Pérouse, and Cherie Taraghi, "Integration in Limbo: Iraqi, Afghan and Maghrebi Migrants in Istanbul," in Land of Diverse Migrations: Challenges of Emigration and Migration in Turkey, ed. Ahmet İçduygu and Kemal Kirişci (İstanbul: İstanbul Bilgi Üniversitesi Yayınları, 2009): 441-636. 


\section{References}

Buğra, Ayşe and Çağlar Keyder. "The Turkish Welfare Regime in Transformation." Journal of European Social Policy 16, no. 3, (August 2006): 211-228.

Castles, Stephen Castles, Derya Özkul and Magdalena Arias Cubas, eds. Social Transformation and Migration National and Local Experiences in South Korea, Turkey, Mexico and Australia. Basingstoke: Palgrave, 2015.

Danış, Didem, Jean-François Pérouse and Cherie Taraghi. "Integration in Limbo: Iraqi, Afghan and Maghrebi Migrants in Istanbul." In Land of Diverse Migrations: Challenges of Emigration and Migration in Turkey, edited by Ahmet Iç̧duygu, and Kemal Kirişci. İstanbul: İstanbul Bilgi Üniversitesi Yayınları, 2009.

Del Carpio, V. Ximena and Mathisi Wagner. The Impact of Syrian Refugees on the Turkish Labor Market. World Bank Social Protection and Labor Global Practice Group, Policy Research Working Paper 7402, 2015.

Dorlach, Tim. "Prospects of Egalitarian Capitalism in the Global South: Turkish Social Neoliberalism in Comparative Perspective." Economy and Society 44, no. 4, (2015): 519-544.

Ferris, Elizabeth and Kemal Kirişci. The Consequences of Chaos: Syria's Humanitarian Crisis and the Failure to Protect. Washington DC: Brookings Institution Press, 2015.

Hickey, Sam and Andries Du Toit. "Adverse Incorporation, Social Exclusion and Chronic Poverty." Chronic Poverty Research Centre Working Papers No. 81. Manchester: University of Manchester, 2007.

Kaşlı, Zeynep and Ayşe Parla. "Broken Lines of II/Legality and the Reproduction of State Sovereignty: The Impact of Visa Policies on Immigrants to Turkey from Bulgaria." Progress in Human Geography 34, no. 2, (2009): 203-227.

Lewis, Hannah, Peter Dwyer, Stuart Hodkinson and Louise Waite. "Hyper-precarious Lives: Migrants, Work and Forced Labour in the Global North." Progress in Human Geography 39, no. 5, (2015): 580-600.

Schierup, Carl-Ulrik, Munck, Ronaldo, Likić-Brborić, Branka and Neergaard Anders, eds. Migration, Precarity, and Global Governance: Challenges and Opportunities for Labour. Oxford: Oxford University Press, 2015.

Sen, Amartya. "Development: Which Way Now?" Economic Journal 93, no. 372, (1983): 745-762.

Standing, Guy. The Precariat: The New Dangerous Class. London and New York: Bloomsbury Academic, 2011.

Zolberg, Aristide. "Wanted but Not Welcome: Alien Labor in Western Development." Population in an Interacting World, edited by William Alonso. Cambridge: Harvard University Press, 1987. 